\title{
SIFAT ORGANOLEPTIK DAGING KELELAWAR DENGAN WAKTU PEMASAKAN YANG BERBEDA
}

\author{
Elisabeth Ruba, Tiltje Andretha Ransaleleh*), Delly B. J. Rumondor, \\ Conny K. M. Palar, John E. G. Rompis
}

Fakultas Peternakan Universitas Sam Ratulangi Manado, 95115

\begin{abstract}
ABSTRAK
Penelitian ini bertujuan untuk mengetahui tingkat kesukaan konsumen pada daging kelelawar yang dimasak karie dengan lama pemasakan yang berbeda. Penelitian ini dilakukan sejak tanggal 27 Juli sampai 31 Agustus 2017 bertempat di Laboratorium Teknologi Hasil Ternak Fakultas Peternakan Universitas Sam Ratulangi Manado. Penelitian ini menggunakan 3000 gram daging kelelawar. Rancangan percobaan yang digunakan adalah Rancangan Acak Lengkap 4 perlakuan dan 30 ulangan. Susunan perlakuan sebagai berikut : R1 = 750 gram daging kelelawar yang dimasak selama 15 menit; $\mathrm{R} 2=750$ gram daging kelelawar yang dimasak selama 30 menit; $\mathrm{R} 3=750$ gram daging kelelawar yang dimasak selama 45 menit; $\mathrm{R} 4=750$ gram daging kelelawar yang dimasak selama 60 menit. Hasil Penelitian menunjukkan bahwa tingkat kesukaan warna, tekstur, keempukan dan cita rasa memberikan pengaruh yang nyata terhadap lama waktu pemasakan daging kelelawar. Namun tingkat kesukaan aroma tidak memberikan pengaruh terhadap lama waktu pemasakan.

Berdasarkan hasil penelitian dapat disimpulkan bahwa waktu pemasakan daging kelelawar selama 60 menit memberikan sifat warna tektur aroma,
\end{abstract}

*Korespondensi (corresponding author) Email : taransaleleh@gmail.com keempukan dan cita rasa yang dapat diterima oleh konsumen.

Kata Kunci: Daging kelelawar, organoleptik, waktu pemasakan

\section{ABSTRACT}

THE

ORGANOLEPTIC PROPERTIES OF BAT MEAT WITH DIFFERENT COOKING TIMES. A study that aims to determine the level of consumer preferences in processed bat meat with different cooking time. This research was conducted from July 27 until August 31, 2017 at Animal Production Technology Laboratory Faculty of Animal Husbandry of Sam Ratulangi University of Manado. This study uses 3000 grams of bat meat. The experimental design used was Completely Randomized Design 4 treatments and 30 replications. Treatment arrangement as follows: $\mathrm{R} 1=750$ grams of bat meat cooked for 15 minutes; $\mathrm{R} 2=$ 750 grams of bat meat cooked for 30 minutes; R3 $=750$ grams of bat meat cooked for 45 minutes; $\mathrm{R} 4=750$ grams of bat meat cooked for 60 minutes. The results showed that the level of favorite color, texture, tenderness and taste gives a real effect on the duration of cooking timebat. However, the level of aroma preferences does not affect the cooking time.

Based on the research results can be concluded that the cooking time of bats meat for 60 minutes gives the nature of color, texture, aroma, tenderness and taste that can be accepted by consumers. 
Keywords: Bat meat, organoleptic, cooking time

\section{PENDAHULUAN}

Berdasarkan jenis pakan, kelelawar dibedakan menjadi dua golongan yaitu kelelawar pemakan serangga dan kelelewar pemakan buah. Kelelawar pemakan buah adalah salah satu satwa liar yang dapat dijadikan sebagai bahan pangan alternatif sumber daging (Ransaleleh et al., 2014), bergizi, dan kaya mineral esensial bagi tubuh (Riley, 2002; Jenkins dan Racey, 2008; Afolabi et al., 2009; Ransaleleh, 2016). Daging kelelawar sebagai lauk merupakan salah satu pangan tradisional alternatif sumber daging selain daging ternak konvensional (Ransaleleh et al, 2013b). Kelelawar sebagai satwa liar dengan aktifitas terbang, memiliki sifat daging tidak empuk dibanding ternak konvensional, selain itu daging kelelawar memiliki bau yang tidak enak akibat kelenjar yang terdapat di sekitar leher. Untuk itu daging kelelawar harus diolah. Pengolahan daging kelelawar biasanya dilakukan secara tradisional berupa masak kari dan rica-rica (Ransaleleh et al., 2013a). Cara pengolahan daging kelelawar dengan penggunaan rempah-rempah, seperti jahe, kunyit, cabe, sereh, daun jeruk, kemanggi, bawang merah, bawang putih, dan santan kelapa, kemudian dimasak, menjadikan daging kelelawar olahan disukai konsumen (Ransaleleh et al., 2013a). Lama pemasakan dapat melarutkan jaringan ikat dan mendenaturasi protein myofibril yang terdapat dalam daging (Nuhriawangsa, 2014). Proses yang terjadi selama pemasakan daging menyebabkan perubahan-perubahan antara proteinprotein myofibril dan jaringan ikat menyebabkan daging menjadi empuk. Keempukan akan semakin meningkat dengan lamanya waktu pemasakan, dimana lama waktu pemasakan mempengaruhi pelunakan kalogen (Gujral, et al., 2002).

Indikator karakteristik daging dapat dilihat berdasarkan sifat fisik, kimia, mikrobiologi, dan organoleptik. Sifat subjektif pangan disebut organoleptik atau indrawi karena penilaiannya menggunakan organ indra manusia, juga disebut sifat sensorik karena penilaiannya berdasarkan pada rangsangan sensorik pada organ indra. Palatabilitas panelis dapat ditunjukan melalui uji organoleptik yang meliputi warna, aroma, tekstur, keempukan dan citarasa (Rahayu, 2001). Penelitian tentang pengolahan daging kelelawar dengan lama pemasakan yang berbeda belum pernah dilakukan. Oleh karena itu perlu dilakukan penelitian sifat organoleptik daging kelelawar dengan waktu pemasakan yang berbeda. 
MATERI DAN METODE PENELITIAN

Penelitian ini dilakukan sejak tanggal 27 Juli sampai 31 Agustus 2017 bertempat di Laboratorium Teknologi Hasil Ternak Fakultas Peternakan Universitas Sam Ratulangi Manado. Bahan yang digunakan adalah daging kelelawar jenis kalong hitam (Pteropus alecto) bagian dada dan paha sebanyak 3000 gram, masing-masing perlakuan digunakan $750 \mathrm{~g}$ daging kelelawar. Bumbu yang digunakan ditimbang terlebih dahulu yaitu bawang merah $200 \mathrm{~g}$, bawang putih $100 \mathrm{~g}$, cabe rawit $60 \mathrm{~g}$, jahe $26 \mathrm{~g}$, sereh $48 \mathrm{~g}$, kunyit $54 \mathrm{~g}$, daun jeruk $4 \mathrm{~g}$, kemiri $50 \mathrm{~g}$, daun batang bawang 266 g, kemangi 50 g, daun kunyit $10 \mathrm{~g}$, garam $34 \mathrm{~g}$, santang kelapa $800 \mathrm{ml}$. Peralatan yang digunakan timbangan digital (Kris Chef Ek9250), gelas ukur, kompor, pisau, baskom, telenan, panci, stopwatch. Untuk pengujian organoleptik air mineral, mentimun dan format uji.

Metode penelitian dirancang menggunakan adalah Rancangan Acak
Lengkap (RAL) (Steel and Torrie,1994). Perlakuan adalah waktu pemasakan daging kelelawar sebagai berikut:

R1 = 750 gram daging kelelawar yang dimasak selama 15 menit

$\mathrm{R} 2=750$ gram daging kelelawar yang dimasak selama 30 menit

$\mathrm{R} 3=750$ gram daging kelelawar yang dimasak selama 45 menit

$\mathrm{R} 4=750$ gram daging kelelawar yang dimasak selama 60 menit Variable yang diamati adalah sifat organoleptik daging kelelawar yaitu warna, aroma, tekstur, keempukan, citarasa. Data yang diperoleh dianalis dengan analisis keragaman (Analisys of Variance), dan yang berbeda nyata diuji lanjut dengan menggunakan Uji Wilayah Berganda Duncan ( Steel and Torrie, 1991)

\section{HASIL DAN PEMBAHASAN}

Hasil pengamatan sifat organoleptik daging kelelawar yang dimasak dengan lama pemasakan yang berbeda dilihat pada Tabel 1. 
Tabel 1. Rataan Sifat Organoleptik Daging Kelelawar Dengan Waktu Pemasakan Yang Berbeda

\begin{tabular}{ccccc}
\hline & \multicolumn{4}{c}{ Perlakuan Waktu Pemasakan } \\
\cline { 2 - 5 } Variabel & $\mathrm{R} 1$ & $\mathrm{R} 2$ & $\mathrm{R} 3$ & $\mathrm{R} 4$ \\
& 15 Menit & 30 Menit & 45 Menit & 60 Menit \\
\hline Warna & $5,90^{\mathrm{a}}$ & $6,07^{\mathrm{a}}$ & $6,27^{\mathrm{a}}$ & $6,57^{\mathrm{b}}$ \\
Aroma & $5,77^{\mathrm{a}}$ & $5,83^{\mathrm{a}}$ & $5,90^{\mathrm{a}}$ & $5,87^{\mathrm{a}}$ \\
Tekstur & $5,80^{\mathrm{a}}$ & $5,83^{\mathrm{a}}$ & $6,20^{\mathrm{b}}$ & $6,37^{\mathrm{b}}$ \\
Keempukan & $5,73^{\mathrm{a}}$ & $5,90^{\mathrm{a}}$ & $6,23^{\mathrm{b}}$ & $6,60^{\mathrm{b}}$ \\
Citarasa & $5,70^{\mathrm{a}}$ & $5,87^{\mathrm{a}}$ & $6,63^{\mathrm{b}}$ & $6,20^{\mathrm{c}}$
\end{tabular}

Keterangan: Superskrip yang berbeda pada kolom yang sama artinya berbeda nyata $(\mathrm{P}<0,05)$

\section{Warna Daging Kelelawar}

Nilai rataan warna daging kelelawar dengan waktu pemasakan yang berbeda dapat dilihat pada Tabel 1. Data tersebut menunjukan bahwa tingkat kesukaan panelis terhadap warna daging kelelawar berkisar dari 5,90 (suka) sampai 6,57 (sangat suka). Hasil sidik ragam menunjukan bahwa waktu pemasakan daging kelelawar memberi pengaruh sangat nyata $(\mathrm{P}<0,01)$ terhadap warna daging kelelawar.

Hasil uji Duncan menunjukan bahwa warna daging kelelawar pada perlakuan 15 menit tidak berbeda nyata dengan perlakuan waktu pemasakan 30 menit dan 45 menit tetapi berbeda nyata dengan perlakuan waktu pemasakan 60 menit. Perlakuan waktu pemasakan 30 menit tidak berbeda nyata dengan waktu pemasakan 45 menit tetapi berbeda nyata dengan waktu pemasakan 60 menit. Perlakuan waktu pemasakan 45 menit berbeda nyata dengan perlakuan waktu pemasakan 60 menit. Semakin lama waktu pemasakan maka tingkat kesukaan terhadap warna daging kelelawar semakin meningkat. Panelis sangat menyukai warna daging kelelawar dengan waktu pemasakan 60 menit karena menghasilkan warna kecokelatan. Warna dapat mengalami perubahan saat pemasakan. Warna cokelat pada daging kelelawar karena terjadinya reaksi maillard. Reaksi maillard adalah reaksi antara protein dengan gula pereduksi (Muchtadi et al., 1993). Kusnandar (2010) menyatakan bahwa reaksi maillard menghasilkan 
pigmen melanoidin yang bertanggung jawab pada pembentukan warna coklat dan reaksi karemelisasi menghasilkan warna coklat melalui reaksi kimia yang terjadi pada gula sederhana kerena adanya proses pemanasan.

\section{Aroma Daging Kelelawar}

Nilai rataan aroma daging kelelawar dengan lama pemasakan yang bebeda dapat dilihat pada Tabel 1. Data tersebut menunjukan bahwa nilai rataan tingkat kesukaan panelis terhadap aroma daging kelelawar berkisar dari 5,77 sampai 5,97 (suka). Hasil sidik ragam menunjukan bahwa lama pemasakan daging kelelawar memberi pengaruh tidak nyata $(\mathrm{P}>0,05)$ terhadap aroma daging kelelawar. Hal ini berarti bahwa waktu pemasakan daging kelelawar masak karie tidak berpengaruh terhadap tingkat kesukaan panelis. Tidak berpengaruhnya aroma daging kelelawar pada pemasakan yang berbeda karena bumbu yang diberikan sama. Ransaleleh (2016) melaporkan bahwa aroma daging kelelawar yang dimasak karie disukai panelis. Zaika et al. (1978) menyatakan bahwa aroma dipengaruhi oleh jumlah bumbu yang ditambahkan ke dalam adonan.

\section{Tekstur Daging Kelelawar}

Nilai rataan tekstur daging kelelawar dengan waktu pemasakan yang berbeda dapat dilihat pada Tabel 1. Data tersebut menunjukan bahwa nilai rataan tingkat kesukaan panelis terhadap tekstur daging kelelawar berkisar dari 5,80 sampai 6,37 (suka). Hasil sidik ragam menunjukan bahwa lama pemasakan memberi pengaruh sangat nyata $(\mathrm{P}<0,01)$ terhadap tekstur daging kelelawar.

Hasil uji Duncan menunjukan bahwa perlakuan lama pemasakan 15 menit tidak berbeda nyata dengan perlakuan waktu pemasakan 30 menit tetapi berbeda nyata dengan perlakuan waktu pemasakan 45 menit dan 60 menit. Perlakuan waktu pemasakan 30 menit berbeda nyata dengan perlakuan waktu pemasakan 45 menit dan 60 menit. Perlakuan waktu pemasakan 45 menit tidak berbeda nyata dengan perlakuan waktu pemasakan 60 menit. Tekstur merupakan salah satu sifat dari suatu produk yang penting diperhatikan, karena erat hubungannya dengan penerimaan konsumen. Tekstur merupakan kualitas yang berkaitan erat dengan keempukan daging (Purwati, 2007). Menurut Fellow (2000), tekstur makanan kebanyakan ditentukan oleh kandungan air yang terdapat pada produk tersebut.

\section{Keempukan Daging Kelelawar}

Nilai rataan keempukan daging kelelawar dengan waktu pemasakan yang berbeda dapat dilihat pada Tabel 1. Data 
tersebut menunjukan bahwa nilai rataan tingkat kesukaan panelis terhadap keempukan daging kelelawar berkisar dari 5,73 (suka) sampai 6,60 (sangat suka). Hasil sidik ragam menunjukan bahwa waktu pemasakan daging kelelawar memberi pengaruh sangat nyata $(\mathrm{P}<0,01)$ terhadap keempukan daging kelelawar.

Hasil uji Duncan menunjukan bahwa pada perlakuan waktu pemasakan 15 menit tidak berbeda nyata dengan perlakuan waktu pemasakan 30 menit tetapi berbeda nyata dengan waktu pemasakan 45 menit dan 60 menit. Perlakuan waktu pemasakan 45 menit tidak berbeda nyata dengan waktu pemasakan 60 menit. Perlakuan waktu pemasakan 60 menit tidak berbeda nyata dengan perlakuan waktu pemasakan 45 menit tetapi berbeda nyata dengan waktu pemasakan 30 menit dan 15 menit. Hasil penelitian menunjukan semakin waktu waktu pemasakan semakin meningkat pula keempukan daging kelelawar, hal ini disebabkan oleh pengolahan panas yang tinggi pada bahan makanan akan menyebabkan terjadinya denaturasi protein. Jamhari et al. (2007) melaporkan bahwa lama pemasakan akan mempengaruhi keempukan daging, dengan meningkatnya waktu pemasakan maka pembebasan cairan daging akan menjadi lebih besar sampai pengkerutan protein miofibrilar dan solubilitas kolagen sudah mencapai maksimal. Daging yang empuk adalah hal yang paling dicari konsumen (Komariah et al., 2004). Semakin menurun nilai daya putus daging maka semakin empuk daging tersebut (Maruddin, 2004).

\section{Citarasa Daging Kelelawar}

Nilai rataan citarasa daging kelelawar dengan waktu pemasakan yang berbeda dapat dilihat pada Tabel 1. Data tersebut menunjukan bahwa nilai rataan tingkat kesukaan panelis terhadap citarasa daging kelelawar berkisar dari 5,70 (suka) sampai 6,63 (sangat suka). Hasil sidik ragam menunjukan bahwa lama waktu pemasakan memberi pengaruh sangat nyata $(\mathrm{P}<0,01)$ terhadap citarasa daging kelelawar.

Hasil uji Duncan menunjukan bahwa perlakuan lama pemasakan 15 menit tidak berbeda nyata dengan waktu pemasakan 30 menit tetapi berbeda nyata dengan waktu pemasakan 45 menit dan 60 menit. Perlakuan waktu pemasakan 30 menit berbeda nyata dengan waktu pemasakan 45 menit dan 60 menit. Perlakuan waktu pemasakan 45 menit berbeda nyata dengan perlakuan waktu pemasakan 60 menit. Hal ini berarti bahwa penelis sangat menyukai daging kelelawar yang dimasak selama 45 menit dibanding daging kelelawar yang dimasak 15 menit dan 30 menit. Panelis sangat menyukai daging kelelawar masak 45 menit karena 
semakin waktu dimasak semakin banyak bumbu yang menyerap kedalam daging, walaupun ada kecenderungan menurun pada pemasakan 60 menit. Setyaningsih et al. (2010) menyatakan bahwa kepekaan terhadap citarasa bervariasi bergantung pada substansi yang diuji, yaitu pada permukaan lidah terdapat sel-sel yang peka terhadap lima rasa dasar dengan urutan kepekaan, yaitu lidah ujung depan peka terhadap manis, tengah depan terhadap rasa asin, tengah belakang asam, pangkal lidah pahit, dan selain rasa dasar terdapat sensasi rasa yang dihasilkan oleh saraf trigeminal yang terletak di rongga mulut dan hidung, seperti rasa pedas, rasa dingin, dan rasa terbakar. Bumbu-bumbu yang digunakan dalam proses pengolahan daging memberikan sensasi rasa pedas, gurih, dan enak. Pengolahan dan pemasakan bertujuan untuk menghasilkan makanan yang bercitarasa tinggi, sehingga rasanya nikmat dan memuaskan bagi yang memakannya (Priwindo, 2009).

Hal ini disebabkan lama pemasakan dapat mempengaruhi kandungan nutrisi daging (Nuhriawangsa, 2004).

\section{KESIMPULAN}

Berdasarkan hasil penelitian dapat disimpulkan bahwa waktu pemasakan daging kelelawar selama 60 menit memberikan sifat warna, tekstur, aroma, keempukan dan cita rasa yang dapat diterima oleh konsumen.

\section{DAFTAR PUSTAKA}

Afolabi, O.O., Y. Adisa, B.E. Awanlenhen, and O. Sumonu. 2009. Determination of major mineral in bats (Chiropterans disambiguation). Continent Jurnal Food Sci Technol 3:14-18.

Fellow, A. P 2000. Food Procesion Technology, Principles and Practise. 2nd ed. Woodreal. Pub. Lim Cambridge. England Terjemahan W. Risanto dan Agus Purnomo.

Gujral, H.S., A. Kaur, N. Singh dan N.S. Sodhi. 2002. Effect of liquid whole egg, fat and textured soy protein on the textural and cooking properties of raw and baked patties from goat meat. Journal of Food Engineering. 53 (4): 377-385.

Jamhari, Edi Suryanto, Rusman. 2007. Pengaruh temperature dan lama pemasakan terhadap keempukan dan kandungan kolagen daging sapi. Buletin Peternakan. 31(2): 94-100.

Jenkins, R.K.B., P.A. Racey. Bats as bustmeat in Madagascar. Madagascar Conserv.\& Develop. 3 (1): 22-30.

Komariah, I. I. Arief dan Y. Wiguna. 2004. Kualitas fisik dan mikrobia daging sapi yang ditambah jahe (ZingerOfficinaleroecoe) pada konsentrasi dan lama penyimpanan yang berbeda. Media Peternakan 28(2): 38-87. 
Kusnandar, F. 2010. Mengenal Sifat Lemak dan Minyak Departemen Ilmu Teknologi Pangan IPB.http:// itp. Fateta.ipb.ac.id/id. Diakses: 12 Desember 2017.

Maruddin. F. 2004. Kualitas Daging Sapi Asap Pada Lama Pengasapan dan Penyimpanan .J Sain Teknol 4(4): 83-90.

Muchtadi, D. 1993. Teknik Evaluasi Nilai Gizi Protein. Program Pasca Sarjana. Institut Pertanian Bogor, Bogor.

Nuhriawangsa, A.M.P., 2004. Pengaruh waktu dan lama pemanggangan terhadap kualitas daging itik afkir. Jurnal Pengembangan Peternakan Tropis. Edisi Khusus November. Halaman 122-127.

Priwindo, S. 2009. Pengaruh Pemberian Tepung Susu Sebagai Bahan Pengikat Terhadap Kualitas Nugget Angsa. Skripsi. Universitas Sumatera Utara. Medan.

Purwati, 2007. The Evektivity of Poliprophy Lene Rigid Air Tight Film In Inhibiting Quality Changes Of Chicken and Beef During Frozen Storage. Skripsi. IPB Bogor.

Ransaleleh T.A, R.R.A Maheswari, P. Sugita, W. Manalu. 2013a. Kandungan mikrobia daging kelelawar yang diolah sebagai bahan pangan tradisional. Jurnal Veteriner 14(3): 294-302

Ransaleleh, T.A., R.R.A. Maheswari, P. Sugita, W. Manalu. 2013b. Identifikasi kelelawar pemakan buah asal Sulawesi berdasarkan morfometri. Jurnal Veteriner 14(4): 485-494.

Ransaleleh, T.A., R.R.A. Maheswari, P. Sugita, W. Manalu. 2014.
Pendugaan produksi karkas dan daging kelelawar pemakan buah (Pteropus alecto) asal Sulawesi. Jurnal Veteriner 15(1): 139-146.

Ransaleleh, T.A. 2016. Komposisi kimia daging segar dan sifat organoleptik kelelawar olahan. Jurnal Zootek 36 (2): 447-465.

Rahayu, W.P. 2001. Penuntun Praktikum Penilaian Organoleptik. Jurusan Teknologi Pangandan Gizi.Fakultas Teknologi Pertanian.IPB. Bogor

Riley, J. 2002. Mammal survey on the Sangiheang Talaud Island.Indonesia and the impact of hunting and habitat loss. Oryx 36: 288-296

Setyaningsih, D., A. Apriyantono, M.P. Sari. 2010. Analisis Sensori Untuk Industri Pangan Dan Agro. IPB press. Bogor.

Steel, R.G.D dan J.H. Torrie. 1991. Prinsip dan Prosedur Statistika Suatu Pendekatan Biometrik. (Terjemahan: Bambang Sumantri). Jakarta PT. Gramedia.

Zaika, L.L., E.Z. Tatiana, S.A. Palumbo, J.L. Smith. 1978. Effect of spice and salt on fermentation of libanon bologna sausage. J Food Science 43:186-189. 